\title{
The Evolution of American Spiritual Communities, 1965-2009
}

\section{Timothy Miller}

\begin{abstract}
The great outpouring of new religious and spiritual movements in the United States after 1965 led to the formation of thousands of spiritual intentional communities. Those communities were based in all the world's major religions, as well as in new expressions of religion articulated by a rising generation of independent spiritual teachers. Many communities gathered around charismatic leaders, and quite a few of them continued after the leader died or stepped down. Over time those communities that survived evolved in form and outlook; in some cases once-authoritative leaders were deposed, and in others the death or departure of a leader led to changes in the group. External social pressure in several cases influenced various groups' developmental trajectories. This paper examines the histories of several religious communal groups, focusing on ones that have survived and exploring the modifications they have undertaken as their members have matured.
\end{abstract}

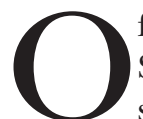
$f$ the plethora of new religions that emerged in the United States after 1965, many are defunct, or essentially defunct; some survive, but in heavily modified form; and a few survive without massive changes. In this article I will describe, rather anecdotally, the evolution of several American new religions, some of them fairly well known, some of them less so, and in keeping with the theme of this issue of Nova Religio, I am confining this discussion to the subset of new religions that practice communal living. As a part of my overall examination of change over time, I will include some that continue to exist communally, some whose communal patterns have undergone major changes, and some that have given up communal living entirely, or nearly so.

Nova Religio: The Journal of Alternative and Emergent Religions, Volume 13, Issue 3, pages 14-33, ISSN 1092-6690 (print), 1541-8480 (electronic). (C) 2010 by The Regents of the University of California. All rights reserved. Please direct all requests for permission to photocopy or reproduce article content through the University of California Press's Rights and Permissions website, at http://www.ucpressjournals.com/reprintinfo.asp. DOI: $10.1525 / \mathrm{nr} .2010 .13 .3 .14$ 


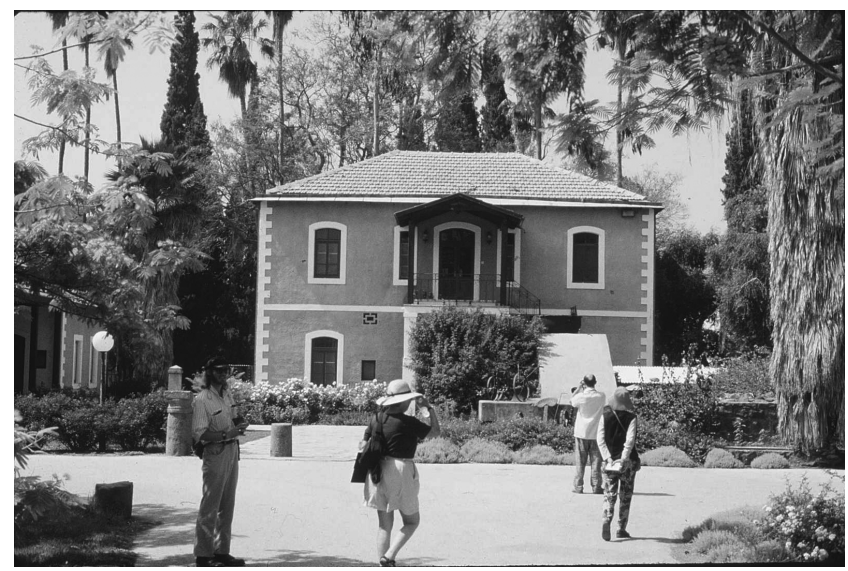

Photo 1. Degania, Israel's First Kibbutz

I am reduced to anecdote rather than comprehensive consideration of all groups because the full dimensions of the American communal world are utterly unknown. I was intrigued when, in 1998, Foster Stockwell published what he presented as a definitive survey of American communes founded between 1663 and 1963, counting exactly 516 of them. ${ }^{1}$ Although his survey is far more comprehensive than anything that preceded it, ${ }^{2}$ in fact he has identified only a fraction of the groups in existence during his time frame. We know the full number of American communal groups in American history, or even just in recent American history, no more than we know the full number of new religions in world history. With such limited data, I think generalizations are hazardous, and I therefore am resorting to anecdote. I do think we can safely generalize, however, that communal groups, and NRMs more broadly, do evolve. Nothing human is static, and groups change just as individuals do.

I began thinking about this topic several years ago when I was invited to go to Israel to talk about the ways in which American communes had changed over time. The context was what Israelis call the "kibbutz crisis." In the century since the first kibbutz, Degania, was founded, the kibbutzim as a group have grown and prospered, but since then they have encountered problems. When the early kibbutzim were founded they were an immensely useful device for promoting Jewish settlement of Palestine. The early settlers were young, idealistic, and poor, and they were moving into an environment that was alien and, often, rather hostile to them. Group settlements were better suited to the conditions of the time and place than individual settlements would have been. However, after the state of Israel was founded in the mid-twentieth century, the need to establish beachheads in unfamiliar territory diminished, 
and new generations of young Israelis did not necessarily have the pioneering optimism, energy for their high cause, and willingness to tolerate harsh conditions that the founders did.

The old guard of the kibbutzim are understandably worried about the future of their movement. New members are too few, and young people tend to grow up and leave the kibbutz, especially when the young members find themselves supporting and caring for growing numbers of aging ones. The situation is rather like that of the Catholic communities, or religious orders.

My topic here is not the kibbutz crisis, but the inevitability of evolution and change in communal groups of all kinds. And so I will examine a few selected religious communal movements founded after 1965 and their changes over a generation and more. I plan to see if there are any lessons to be drawn from those changes. The groups under consideration do have certain similarities and differences that I will outline later in this paper, and each tends to model one of three broad historical patterns: continuation with little change from the forms and ideals and patterns a community established in its founding years; continuation with substantial modifications (such as changes in economic structure or patterns of residence); and dissolution or near-dissolution of the communal structure even if, as sometimes happens, members of the former community continue to live as neighbors at the original communal site. But even within these three broad patterns there is a good deal of diversity among the movements in question. One of my goals here is to illustrate the difficulty of making accurate generalizations about such a diverse group of phenomena as communal religious movements, much less alternative religions more inclusively.

My subject communities have been chosen for several interrelated reasons. One is simply the variety of their historical trajectories, that is, the divergent paths that they have taken over time. Another is that they embody some of the great variety in grounding that communal new religious movements have displayed in the United States: here we have communities with roots in American Christianity, in three different religious traditions from Asia; and, with "none of the above," two communities that had charismatic founders/leaders who fashioned their own rather eclectic messages that were not strongly based in any major world religious tradition. A third reason is that most of these communities are not as familiar to scholars as are much-studied movements such as the Family Federation for World Peace and Unification (formerly the Unification Church), the Family International (formerly the Children of God), and the International Society for Krishna Consciousness. I want to expand the academic playing field, because the world of American religious communities is much larger and more diverse than is generally appreciated. A fourth reason for the choices I have made is that I have good research resources on these communities: published 
scholarly work, in some cases (including, sometimes, the work of inhouse scholars; these groups tend to have well-educated memberships), and in most of the cases, my own archival oral histories gathered by my research colleague Deborah Altus, many of my students, and myself over nearly three decades.

I will tell the stories of my six subject groups individually, and will provide, in endnotes, references to a few basic primary and secondary sources on each of them.

\section{SOME CASE HISTORIES}

\section{Twelve Tribes}

I begin by examining the Messianic Communities, or Twelve Tribes, a federated group of communities that has remained largely on track with its original purpose and whose most notable change over nearly four decades is simply growth in both membership and number of local communities. The Messianic Communities had their origin in a coffeehouse that opened in Chattanooga, Tennessee, in 1972. Elbert and Marsha Spriggs in many ways exemplified the essence of the Jesus Movement: they were idealistic, they were energetic, and their social and theological outlook was conservative. In the classic style of the day, new converts who came through the coffeehouse ended up living in the Spriggs home. So many came that new premises were soon required, and before long the nascent movement had five communal homes and a business, which expanded from the coffeehouse into a health food restaurant. Like many communes of the era, the young Christian collective soon faced conflict with its neighbors, especially, given its location in the American South, over its practice of racial integration in its houses. Rather than endure protracted controversies, the community members moved as a group to Island Pond, a town of just over a thousand in the isolated far northern reaches of Vermont. From that base they expanded to other places. The Twelve Tribes website recently listed twenty-six communities in the United States, most of them in rural locations, five in Canada, and thirteen abroad in Argentina, Australia, Brazil, England, France, Germany, and Spain.

The Twelve Tribes communities adhere to the biblical injunction to "depart from their midst, and set yourselves apart from them."3 Beyond living in fairly isolated locations, they operate their own businesses (restaurants, natural products stores, woodworking shops), homeschool their children, and practice a distinctive Judaizing form of Christianity, observing the Friday/Saturday Sabbath and using Hebraic terminology (Jesus is Yahshua, for example, and members get new Hebrew names). Most who are accustomed to the comfort-laden 
lifestyle of industrialized countries would find their life austere. Members live in close quarters, with limited personal space, and eat and work and worship together. Marriage is strongly emphasized, and wives are to be submissive to their husbands. Children are strictly disciplined. The Twelve Tribes have not escaped controversy. In 1984 their community in Island Pond was raided by local authorities and 112 community children were taken from their homes pursuant to a charge of child abuse filed by a disaffected former member. The children were quickly returned when the state could produce no evidence of abuse, but other similar controversies centering on the children have occurred in other Twelve Tribes communities. ${ }^{4}$ In the end, the movement seems to have been legally vindicated in these cases.

The story here is not one of a community that suffered an early death, or succumbed to internal squabbles, or was dismembered by external opposition, or "matured" into a less controversial movement than it had been in its earlier days. At this point in the history of the Twelve Tribes, the movement seems to be pretty much what it set out to be. Change may be inevitable, but one of the few notable changes in the Twelve Tribes is unusually strong growth. ${ }^{5}$

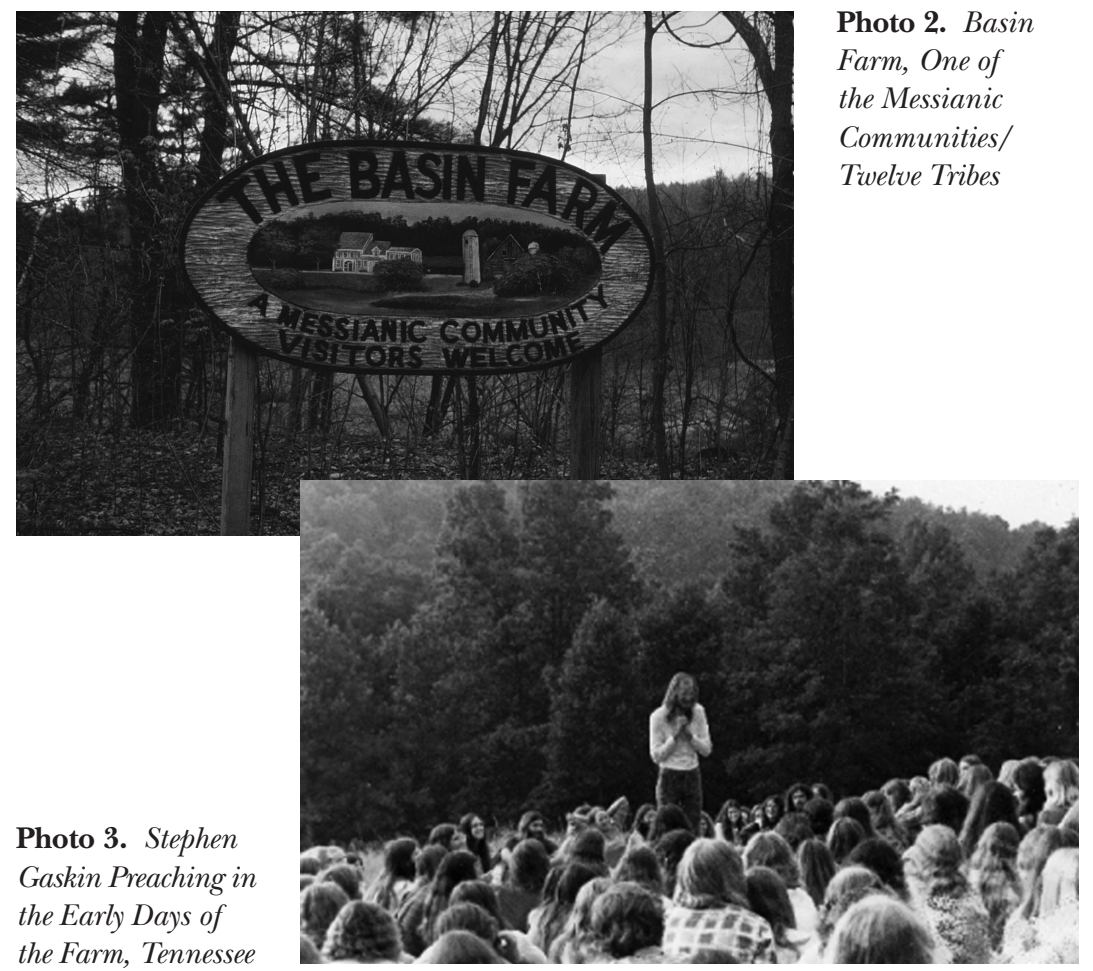



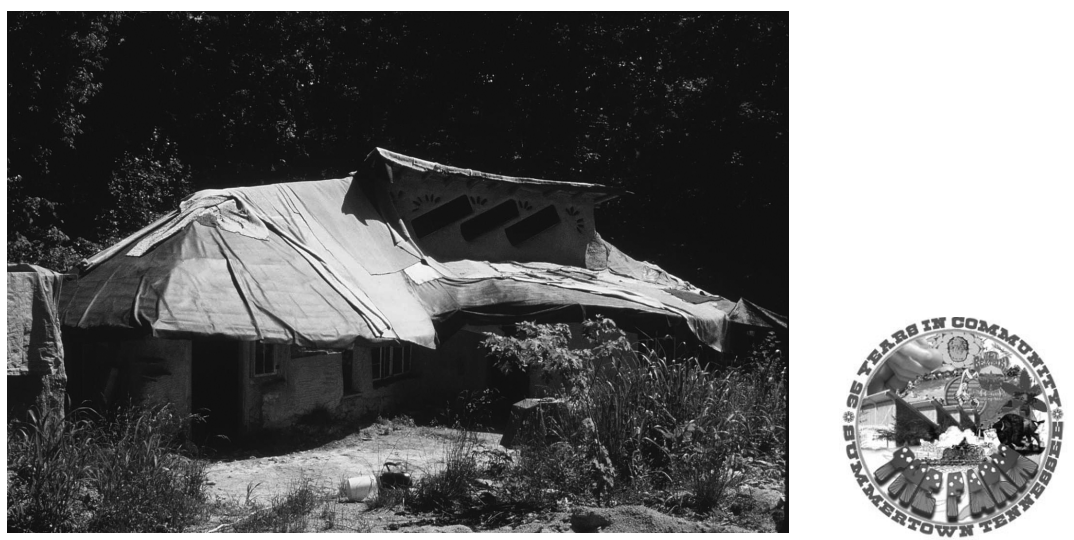

Photo 4 (left). Alternative Structures: A Cob Building at the Farm, Tennessee

Photo 5 (right). The Farm (Tennessee) celebrates its 35 th anniversary with a new logo

\section{The Farm}

Another enduring community with distinctively religious foundations is the Farm of Summertown, Tennessee. Its development has been quite different than that of the Twelve Tribes, however. Although many Farm members undoubtedly still see the spiritual quest as central to their lives, the specific and distinctive spiritual path of the community's early days is essentially nonexistent.

The Farm had its origins in the heyday of the counterculture in San Francisco. Stephen Gaskin, an assistant professor of English and creative writing at San Francisco State College in the late 1960s, became so popular that he outgrew his campus appointment and began hosting larger and larger groups of fellow seekers in locations around the city. By 1969 his Monday Night Class, as it became known, was attracting thousands every week to a large auditorium; the session began with group meditation, and then went on for hours as Stephen (as he was always called) provided discourses and led discussions that covered virtually the whole spectrum of the world's spiritual and esoteric traditions, from astral projection to Zen. ${ }^{6}$ As Stephen himself frequently observed, there was really nothing new in his teachings, but he put together a vast array of teachings in a remarkably original way. Among other things, he taught that one had a profound obligation to put the best of the world's ethical teachings at the center of one's life. Those joining him in the spiritual quest were to be honest in all their dealings, to follow the Golden Rule, and to accept the Hindu/Buddhist law of karma, which teaches that we reap what we sow in the daily actions of our lives. One of the most distinctive parts of Stephen's teaching, and one thoroughly in tune with the ethos of the 1960s era, was an acceptance, and even advocacy, of the use 
of psychedelics, entheogens, and other substances that could enhance the spiritual quest. Stephen's classic statement of position was "We believe that if a vegetable and an animal want to get together and can be heavier than either one of them alone, it shouldn't be anybody else's business." 7

Word of Stephen's work soon spread beyond San Francisco, and he began to receive invitations to speak on college campuses and elsewhere. In 1970 he announced that he would soon be going on a speaking tour, and many of the devout Monday Night Class members quickly decided that they wanted to go along. The speaking tour became a lengthy caravan of old school buses and other vehicles that traversed thousands of miles. ${ }^{8}$ Eventually the travelers decided that they wanted to settle together and start a permanent spiritual community. In 1971 they ended up on a tract of rural land in south-central Tennessee, and there began to build the Farm.

Farm members, all of whom accepted Stephen as their spiritual teacher as a condition of membership, sought to be self-sufficient in all things. They labored mightily to raise the ingredients of their vegan diet and along the way developed such new comestibles as soy-based ice cream. They delivered their own babies and developed a world-class crew of midwives whose services were available at no charge to any woman who arrived at the Farm. They constructed housing (including many remodeled school buses) for a membership that eventually reached about 1,500, and built their own telephone system that they called Beatnik Bell. They sought to help the less fortunate both in their neighborhood and abroad through a charity called Plenty, with projects ranging from earthquake relief in Guatemala to a free ambulance service in the Bronx, New York. With the main Farm bursting at the seams, they opened satellite Farm communities in such far-flung locations as Missouri, Wisconsin, and Florida. Through it all the spiritual center of the community remained strong, with group meditation and Sunday morning services featuring Stephen's discourses. ${ }^{9}$

It all worked fairly well for about a decade, but eventually the Farm's communal economy failed to meet the community's needs and rising expectations. In 1983 the members voted to privatize the economy; residents would have to pay dues to live in the community, and therefore would need jobs, either on or off the Farm. Many hundreds left.

Others stayed, however, and over the next few years the Farm achieved a new stability. Gaskin was demoted from his position of spiritual and temporal leader, essentially because the Farm needed more effective financial management, but he soon accepted that collective decision and has remained at the Farm as a regular member ever since. Today the considerably smaller community of about 200 members, governed by committees rather than by one charismatic leader, remains a center of innovation and progressive thought. On one corner of the 
Farm the Ecovillage Training Center, headed by longtime Farm member Albert Bates, is helping a whole generation of young idealists learn skills for sustainable living, from construction to farming to waste disposal. ${ }^{10}$ An early commitment to oppose nuclear power has led to a cottage industry that produces sophisticated radiation detectors. The Mail Order Catalog at the Farm ships vegan foods and books on natural living worldwide. Stephen has acquired a tract of land adjacent to the Farm where he is overseeing the development of Rocinante, a hippie retirement commune. ${ }^{11}$ The Farm is not what it was in its first decade, but it continues as a community and the core spiritual vision it embodied may be said to continue, even without the direct leadership of its charismatic spiritual teacher. ${ }^{12}$

\section{Divine Light Mission}

Stephen Gaskin is, of course, not the only communal religious leader to have lost his or her dominant position in a communal new religious movement. A rather different version of a departure of a leader occurred in the Divine Light Mission (DLM), one of the largest of the 1960s-era communal movements imported from Asia. Once again a strong charismatic leader was behind the rise in the American movement, in this case an Indian teenager known as Guru Maharaj Ji. His father had been influenced by the Sant Mat tradition in the 1920s, and by the 1940s had a substantial Indian following. The father, known as Shri Hans Ji Maharaj, was considered a perfect master by his followers, and following his death in 1966 his son, then only eight years old, assumed his role and took over the leadership of the organization. He first visited the United States in 1971, at the age of thirteen, and by the following year had a considerable Western following.

The movement quickly developed a considerable communal component as the dedicated members moved into dozens of ashrams and other group homes in American cities and college towns. Members pooled their resources and possessions in the service of the beloved Maharaj Ji. Such was their devotion to their perfect master that they went to great lengths to travel the country, and even the world, to be in his presence at his public appearances.

The high-flying early success of the movement was short-lived, however. A large rally called "Millennium 1973" turned out to be a major flop. 1974 was a fateful year; the guru, supposedly celibate until then and still only sixteen years old, suddenly married his secretary. Many of the members who had been living in celibate ashrams were dismayed, or at least confused, by the master's sudden change of course, and Maharaj Ji's own family severed the large Indian branch of the movement from his control. Nevertheless, the DLM persevered with a somewhat reduced membership until Maharaj Ji decided to bring the 
organization itself to an end. In the early 1980s he directed that the ashrams be closed and the communal businesses dissolved. No longer claiming to be a perfect master, he simplified his official name to Maharaji (and later changed it to Prem Rawat) and undertook the life of a public speaker. Many of his former followers continued to attend his talks, and in many places they continued to gather locally for meditation. The movement, renamed Elan Vital, became a shadow of its former self, however.

The case of Maharaj Ji and the Divine Light Mission is an unusual one in the history of charismatic leadership. The authority of the guru, at least among his American followers, was unquestioned, and although many followers were disillusioned by his marriage, no one made any attempt to remove him from his position or even to reduce his authority. It was Maharaj Ji himself who decided to leave the role of spiritual master, becoming instead a lecturer and family man. Thus he continues today. ${ }^{13}$

\section{Ananda}

Another community with religious roots in an Indian religious tradition has had crises and conflicts of several kinds, but has managed to weather them all and continues in relatively stable fashion more than forty years since its founding. What is now Ananda World Brotherhood Village was founded in 1968 by Donald Walters, who until a few years earlier had been a member of the Self-Realization Fellowship and considered himself something of a protégé of the SRF's founder, Paramahansa Yogananda. Walters was an SRF monk from 1948 until 1962, eventually taking the spiritual name of Swami Kriyananda and rising to the vicepresidency of the SRF. In that year, however, he was rather unceremoniously expelled from the organization, apparently for making independent decisions and harboring the potential for causing schism in the movement. ${ }^{14}$ Walters regrouped and dedicated himself to fulfilling one task Yogananda had embraced, the founding of "world brotherhood villages," rural intentional communities where the committed could develop their spiritual lives and live in a manner that would isolate them from looming social disasters.

Ananda was founded on a part of a piece of land that Walters purchased in cooperation with the beat poet Allen Ginsberg, Zen master (and later, for a time, head of the San Francisco Zen Center) Richard Baker, and poet Gary Snyder. With a band of followers he began to build a spiritual village in the foothills of the Sierra Nevada mountains. ${ }^{15}$ The Ananda pioneers pitched in heartily to give shape to the dream, working at length to get the requisite approvals from the local zoning and planning authorities. And then the first great crisis intervened: on 28 July 1976, a fire swept through the area and destroyed most of the community's buildings. ${ }^{16}$ 
Although the community was devastated both financially and physically by the blaze, members somehow managed to regroup and, with redoubled effort, were able to build a community that was larger and more prosperous than the original one. Over time more land was purchased, pushing the community's holding to more than 800 acres, and resident membership surpassed 200. The communal economy of Ananda's early days was dropped in favor of a cooperative system in which individuals maintained separate finances. That system seems to have served the community well.

A challenge to the community surfaced in 1990, when the SelfRealization Fellowship sued Ananda over the latter's publication of the writings of Paramahansa Yogananda, the use of his image, and alleged infringement of an SRF trademark when Ananda began to use the name "Church of Self-Realization." The legal struggle lasted a dozen years; in the end, Ananda largely prevailed and was allowed to publish Yogananda's signature work, Autobiography of a Yogi, ${ }^{17}$ as well as to use the master's image and to call itself "Ananda Church of Self-Realization."

A third crisis came in the late 1990s, when Ann-Marie Bertolucci, a former member, accused Walters and another Ananda leader of sexual misconduct. Although the lawsuit was settled, Ananda was forced into bankruptcy in the process. Meanwhile, community life goes on much as before.

Walters is no longer the official community leader, but he retains his eminence. Over the years Ananda has expanded, and in 2009 had six residential communities in addition to the original one: four in the United States, one in Italy, and one in India. It also has more than one hundred teaching centers and meditation groups around the world.

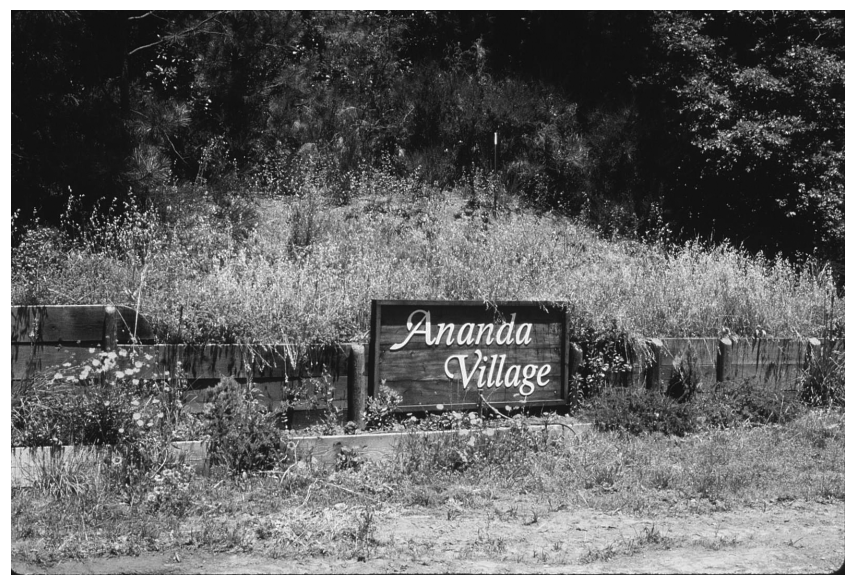

Photo 6. Ananda Village, California 


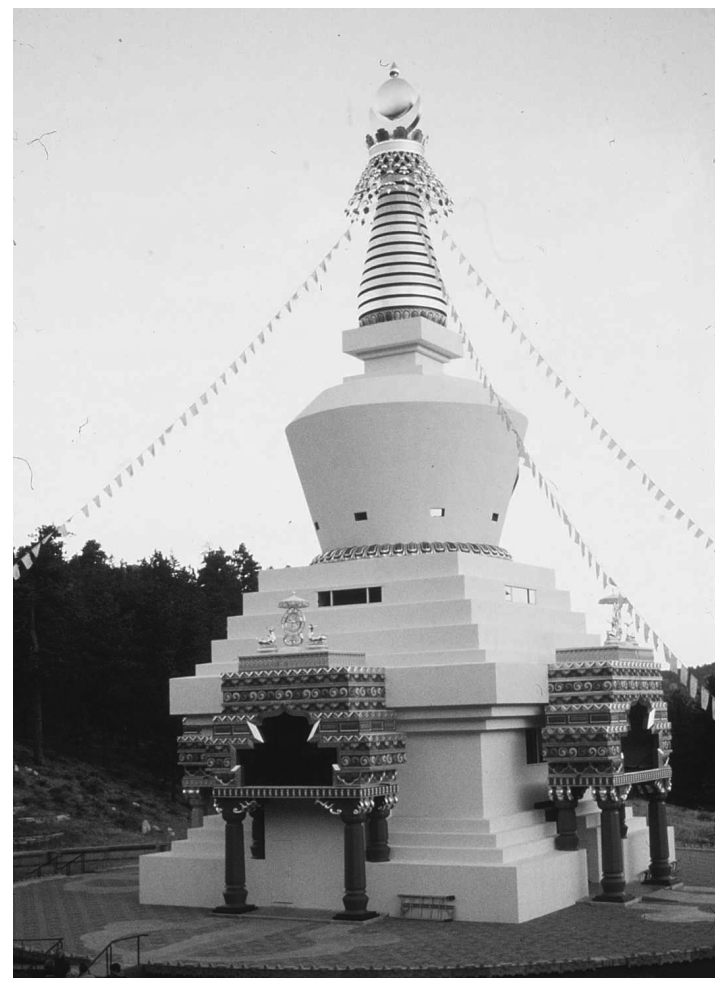

Photo 7. The Great

Stupa at Rocky Mountain

Shambhala Center

Despite years of legal and physical obstacles, Ananda has not only survived but has prospered. ${ }^{18}$

\section{Shambhala Mountain Center}

Yet another pattern has characterized the history of what is now the Shambhala Mountain Center, a Tibetan Buddhist communal enclave outside Red Feather Lakes, Colorado. The Center had its origins in a group informally known as the Pygmies, adherents of a small independent spiritual movement called Bodhisalism, which combined magic, LSD, and Tibetan Buddhism. The Pygmies first came together in Chicago, but by the late 1960s had moved to New Orleans, and then, when the members decided to develop a rural commune, to Colorado, where they established the Pygmy Farm near Boulder.

In 1970 the newly-arrived Tibetan teacher Chögyam Trungpa visited the Pygmy Farm, and most of the members were so taken with his teachings that they joined his movement. After a time they lost the lease on their farm, and Trungpa, whose following was increasing steadily, helped them locate and move to a new property in the Rocky Mountain foothills north of Boulder. 
Initially the Rocky Mountain Dharma Center, as it was originally known, fit the stereotype of a hippie commune quite well. The residents were spiritual seekers, but did not live in a very disciplined environment. Eventually Trungpa, himself not the most austere of spiritual masters (he was known for his drunken rages and his womanizing, among other things), cracked down on his free-form followers, telling them, in particular, to quit smoking marijuana. Just how long the transition took is not entirely clear, but eventually the commune became a major center for Trungpa's Shambhala movement, and eventually was renamed the Shambhala Mountain Center. In the late 1980s, shortly after Trungpa's early death, Center members began work on the Great Stupa of Dharmakaya, which the Center describes as the largest Buddhist structure in North America. The stupa was finished in 2001 and has attracted many visitors to the Center.

Thus we have a bit of evolution in communal form here, but a kind of evolution that might be described as maturation and deepening of sense of purpose. Today the Shambhala Mountain Center is one of the largest and most important Buddhist centers in the United States, and indeed the Western world. ${ }^{19}$

\section{Renaissance Community}

One last religious community does not fit into any of the categories of new religions as neatly as do the majority of the communities discussed so far. What through much of its life was known as the Renaissance Community was founded by a high-school dropout, Michael Metalica, who spent the Summer of Love (1967) in San Francisco and returned to his Massachusetts home a spiritual seeker soon thereafter. He built a tree house in which to live the solitary life, but he was quickly joined by others of similar outlook. They soon expanded into a summer-camp dormitory building. In the meantime, Metalica's own spiritual search was heavily influenced by a local trance medium, Elwood Babbitt, who foresaw catastrophic changes in the world's immediate future, after which new spiritual movements would be needed to repair the devastating damage the earth would have experienced.

Metalica and his growing band of associates, who took the name Brotherhood of the Spirit, bought their first real estate in 1970, purchasing twenty-five acres of land in Warwick, Massachusetts. The group, by then numbering about 150 , soon purchased other land and buildings as well, and built a large dormitory that was soon crammed with young communards. People kept coming, and by the mid-1970s membership reached 300. Members raised and preserved food, erected buildings, and operated several small businesses for self-support. One major communal focus was the community's band, Spirit in Flesh, although the band's public reception was generally less than enthusiastic. 
The mid-1970s was a lively and turmoil-filled time for the group, which in 1974 was renamed the Renaissance Community. Metalica changed his name to Michael Rapunzel and was increasingly the sole authority for all community activities and decisions. His charismatic leadership became more and more erratic, however, as his substanceaddiction problems became ever more obvious, although the community's specialized businesses continued to produce enough income to keep everyone fed and to keep Michael in drugs. Nevertheless, in the early 1980s many of the most productive and stable members left, and the community's once-vital life waned. Rapunzel's situation grew so problematic that other community leaders finally offered him a large amount to cash to leave permanently, which he did. He ended up in New York state, tried to work through his addictions, and died of cancer in 2003.

The Renaissance Community as it was during its heyday is long gone, but as early as the 1970 s some members became interested in alternative energy and sustainable building practices. In 1976 they bought an additional tract of eighty acres of land they called the 2001 Center and soon began to build homes, cultivate gardens, and develop innovative technological devices. ${ }^{20}$ Today the houses are in private ownership, and an intentional community in the economic sense of the term is long gone, although the community did keep a listing in the Directory of Intentional Communities into the $1990 \mathrm{~s} .{ }^{21}$ Even thereafter community members continued to think of themselves as constituting a "cooperative neighborhood," with like-minded people living in close proximity and at least sometimes working on projects of common interest. ${ }^{22}$ That neighborhood is the last residential legacy of the Renaissance Community, although the influence of the community continues to be felt in the lives of its onetime members. ${ }^{23}$

\section{And many more}

This survey has focused on groups that have survived, with or without major changes, since their origins in the 1960s era. It should be noted that a great many have not survived; instead, the kinds of circumstances and pressures I have described above have led to the demise of hundreds, probably thousands, of them. The Shiloh movement, for example, was the largest of the communal networks of the Jesus Movement. Having its roots in several rather informal communal houses that sprang up with the support of the Calvary Chapel megachurch in southern California in the late 1960s, the Shiloh Youth Revival Centers, to use the movement's formal name, developed a headquarters commune near Eugene, Oregon, and ultimately had more than 175 local communal outposts. Poor business management weakened Shiloh, however, and eventually the Internal Revenue Service seized the Oregon 
land to cover unpaid taxes. Shiloh, which once had had thousands of members, closed in $1989 .{ }^{24}$ Its land is now occupied by a secular community called Lost Valley Educational Center that offers conferences and workshops in sustainable living and personal growth. A rather different spiritual movement, the Source Family, charismatically led by an eclectic spiritual teacher the members called Father Yod, or YaHoWha, had a membership of about 150 and a solid financial base in a Hollywood natural foods restaurant popular with celebrities, but came apart when as a group the members left their restaurant, moved to Hawaii, and struggled both economically and socially until Father Yod died in a hang-gliding accident in 1975, in the wake of which the community disbanded. ${ }^{25}$ Some communities change and survive; some change and eventually disappear.

\section{HOW THINGS CHANGED, AND WHY}

To wrap up this exercise in retrospection I will try to offer some general speculations regarding communal change, maturation, development, and deterioration. As I mentioned at the outset, however, I find the identification of general patterns in communal history difficult, if not impossible. As far as I can tell, there are just about as many specific trajectories as there are communitarian groups. On the other hand, the unique paths communal groups follow have some common elements, and perhaps an identification of such elements will help provide some broader insights. What did, or do, the communities just characterized have in common? Apart from the baseline fact that they all are or were based on religious convictions and involved communal living, one characteristic stands out: a countercultural stance toward the larger society. Communal living is a radical step for the average American to take. A whole-hearted $24 / 7$ commitment to an ideal that involves a rejection of the prevailing society's values and lifeways and, sometimes, creature comforts, is not attractive to very many of us. Joining a commune inherently entails a rejection of all kinds of American predilections. The six communities were also all founded in bursts of idealism by members who were mostly young adults. And another commonality is that they all faced pressure from a skeptical outside public-something that seems inescapable for any group, communal or not, that is perceived as outside the cultural mainstream. Finally, they were all founded under charismatic leadership.

But the differences among the six communes, I would argue, outweigh the similarities. One important difference has to do with the maintenance of the spiritual fervor that in each case marked the community's founding. In some cases, the spiritual side of the experience declined, or at least changed, over time. At the Farm, for example, Stephen Gaskin stepped down from the role of spiritual teacher, and 
gradually members began to see themselves as spiritual searchers, but not members of any single movement or religious organization. The spiritual decline was even sharper at the Renaissance Community. However, there is no evidence that any measurable decline or change has taken place at the Twelve Tribes communities, where fervor seems as strong as ever and not changed in its nature. If anything, the story at the Shambhala Mountain Center has been the opposite of decline. In its early years the members were not very strictly disciplined in their spiritual lives, but eventually rigor was imposed on the community, and it has continued in a more ordered way ever since.

Similarly, the six communities have diverged sharply in their levels of communal commitment. The Twelve Tribes communities remain highly communal; members pool their assets, their incomes, their living spaces, their jobs, communal domestic duties (cooking, cleaning), their childrearing, and just about everything else but their toothbrushes. At the Shambhala Mountain Center the communal core of things also remains strong. But communal life at the Farm, once as strong as that of the Twelve Tribes, has been reduced to common ownership of the land and informal cooperation among residents, and at the Divine Light Mission/Elan Vital, communal living has disappeared entirely.

What causes these movements to change over time, and what forces affect different communities in very different ways? Most broadly, we could divide causes of change over time into two large categories, internal and external. Some of the internally-produced causes of communal change can be such things as changes in leadership and maturation of membership. Changes in leadership are always important, especially in movements that have not reached advanced stages of bureaucratization and routinization. The powerful role that a charismatic leader often plays in a given religious or social movement has been a prime focus of scholarly discussion at least since the time of Max Weber, ${ }^{26}$ and a change in leadership in such a movement inevitably means the end of the leader-follower relationship that is the essence of what we commonly call charismatic leadership. Even when a movement's leader might not plausibly be characterized as charismatic (an able and sensitive bureaucrat can, for example, also keep an organization vital), leadership transition can have a powerful effect on any organization.

Another internal cause of change in a religious movement, one that can be less obvious and dramatic than a change in leadership, is the maturation of a community's membership. A truly stable community with multigenerational membership should be able to survive maturation and turnover among members fairly well, but in reality a great many communal movements are initially populated by relatively young members whose commitment is strong enough to cause them to stay in the movement for a long time, perhaps for life, and as they grow older their needs and outlooks will inevitably change in ways that can affect the 
movement itself. Those who join when they are in their early twenties, for example, will probably not at that time have children and will be able to devote a great deal of their time and energy to the movement. Later, however, children may have entered the scene, and, even if they have not, the members may lose some of their youthful zeal as they move into middle age and beyond. If maturation of members is balanced by a continued intake of younger ones, then the net effect on the movement of the aging of original members may be minimal. Otherwise the movement may find itself changing radically over time.

Although internal situations such as changes in leadership and maturation of membership can have a profound impact on communal and other religious movements, external causes of change can be important as well. One source of pressure on a religious movement can be a change in the ethos of the prevailing society. A movement that had a strong female membership in the early 1960s, for example, could hardly have failed to have been affected by the rise of contemporary feminism over the next decade and thereafter; as opportunities for women expanded in the larger society, women of talent and ambition in communal groups, especially the more patriarchal ones, might plausibly have come to harbor some desire to expand their social roles. Members of even the most insular commune are not unaffected by larger social currents. The rise of contemporary environmentalism could similarly have an impact on a community. As social expectations for more sustainable living patterns increase, communitarians might have their practices questioned, or, on the other hand, they might be seen as models of sustainability and attract numbers and types of new members whose presence would cause significant change in the movement.

One other external cause of pressure on intentional communities has been little discussed by communal historians, but may be one of the most significant of all. I refer to zoning regulations. Zoning ordinances are increasingly widespread in the United States and elsewhere, and they are becoming ever more stringent. In some cases they have already had devastating impact on communities, inhibiting their expansion, at a minimum, and putting them out of business entirely at a maximum.

Zoning's threat to communal living is not merely hypothetical. One group whose demise was due in large part to zoning issues was the Israel Family of Washington state. A community began to coalesce around Paul Erdman, who took the spiritual name Love Israel, in the late 1960s. Its membership eventually reached some 400 , housed in residences in the Queen Anne Hill neighborhood of Seattle. In 1983 internal conflict split the group, and a smaller Israel Family, with around fifty members, moved to a ranch near Arlington, north of Seattle. But local zoning and land-use laws made it illegal for so many people to live together, and years of conflict between the Israels and the authorities ensued. Finally the Israel Family declared bankruptcy in the early 2000s and gave up the 
land. A core group is regrouping in northeast Washington, far from Seattle; perhaps in that more thoroughly rural area zoning laws will be more lenient.

The fact is that zoning nearly everywhere is anticommunitarian. In my home county in Kansas, by no means the most stringently zoned of localities, no more than four unrelated persons may live on a single piece of property, no matter what its size, and no more than one house may be built on any single parcel of land. Larger parcels of land may be split up, of course, but in rural areas the minimum required for a house is at least three acres, and in many cases more than that. Thus the building of several closely clustered homes, as well as large communal dwellings, is forbidden by the zoning code. Within the city limits of my town of Lawrence the requirements are even more restrictive. Except in a dense neighborhood of student housing on one boundary of the university, no more than three unrelated persons may live in any one house, and houses may only be built on separate pieces of real estate under regulations that have the effect of keeping intentional communities out.

In such zoning environments communal living is virtually impossible. There remain localities in the United States where zoning is lax or even nonexistent, but in many of the most desirable parts of the country zoning laws make it exceedingly hard to start a community today. And external pressure applies to existing communities as well, since many of them do not conform fully to building codes and other regulations. One commune in the western part of the United States has some sixty members living utterly illegally on a beautiful tract of rural land, and the members do everything in their power to keep their profile low in the hope that they can simply continue to live the way they have been for more than thirty years. The widespread public fear of new religious movements takes a particularly heavy toll on communal groups.

Neither internal nor external pressure on communal groups operates to the exclusion of the other. Indeed, both are often present. A classic case of change caused by both internal and external factors is that of Latter Day Saints, who experienced a shift from charismatic to more routinized leadership in their main (now Salt Lake City-based) church. They saw an evolution in the outlook of their members, and felt considerable external pressure over their practices of polygamy and, later, overt discrimination against African Americans. Mormonism has evolved considerably in its social presence over its 180 years of existence, and internal and external pressures have both been profound. Although the Mormons have not been entirely communal throughout their history, they have had many communal episodes both within and outside the principal church, and dozens, at least, of the splinter groups that have left the main church have adopted communal living as a lifestyle. Major institutional changes have been considerable among communal and noncommunal LDS groups. 
Thus it is with most communal religious movements. Communal evolution has many causes and takes many diverse paths. Tens of thousands of intentional communities have appeared in America since the beginning of European settlement, many of them founded by leaders with widely diverse communal visions and all of them populated by the endlessly free-spirited species homo sapiens. They have been buffeted by external social pressure and by internal crises of economics, leadership, and changing expectations of members. Finding overarching patterns in the complex mosaic of communities seems destined to remain elusive.

\section{ENDNOTES}

${ }^{1}$ Foster Stockwell, Encyclopedia of American Communes (Jefferson, North Carolina: McFarland, 1998).

2 To my knowledge, only two other works have identified more intentional communities than Stockwell has. One is the appendix to Donald E. Pitzer, ed., America's Communal Utopias, (Chapel Hill: University of North Carolina Press, 1997); the other is the appendix to my own The 60s Communes (Syracuse: Syracuse University Press, 1999). Together those two lists, which cover largely separate time periods, identify well over 2,000 communities. But both are simply lists, with few particulars and no references.

${ }^{3}$ II Corinthians 6:17 (my translation).

${ }^{4}$ Jean Swantko and Ed Wiseman, "Messianic Communities, Sociologists, and the Law," Communities no. 88 (Fall, 1995): 34-35; Isaac Dawson, "My Son Michael," Communities no. 88 (Fall, 1995): 36-38.

${ }^{5}$ Susan J. Palmer is one of the relatively few scholars to have published studies of the Twelve Tribes communities. One chapter in her Moon Sisters, Krishna Mothers, Rajneesh Lovers: Women's Roles in New Religions (Syracuse: Syracuse University Press, 1994) examines the roles of women in the communities; her article "Frontiers and Families: The Children of Island Pond," in Children in New Religions, ed. Susan J. Palmer and Charlotte E. Hardman (New Brunswick, New Jersey: Rutgers University Press, 1999), 153-77, does a similar examination of the communities' children. Palmer also has an article on the Twelve Tribes in this issue of Nova Religio. Twelve Tribes member Jean A. Swantko, an attorney, has written extensively about the movement and has published some of her work in peer-reviewed journals. See, for example, "The Twelve Tribes' Communities, the Anti-Cult Movement, and Government's Response," Social Justice Research 12, no. 4 (December, 1999): 341-64.

${ }^{6}$ Stephen [Gaskin], Monday Night Class (San Francisco: The Book Publishing Company, 1970).

${ }^{7}$ Stephen Gaskin and the Farm, Hey Beatnik! This Is the Farm Book (Summertown, Tenn.: Book Publishing Company, 1974), unpaginated.

${ }^{8}$ Stephen [Gaskin], The Caravan (New York and Berkeley: Random House and Bookworks, 1972). 
${ }^{9}$ Some of Stephen's talks were published in book form. See, for example, Stephen Gaskin, Volume One: Sunday Morning Services on the Farm (Summertown, Tenn.: Book Publishing Company, [1977]).

10 Albert Bates, "A Training Center for Ecovillagers," Communities no. 91 (Summer, 1996): 34-35.

${ }^{11}$ On Rocinante, see Tim Neville, "Birds of a Feather," New York Times (6 April, 2007): D1, D8.

12 The definitive scholarly monograph on the Farm remains to be written, although several theses and dissertations have appeared since the Farm's early days. See, for example, Pat LeDoux, "The History of a Hippie Commune: The Farm," Doctor of Arts diss., Middle Tennessee State University, 1992. Farm members have done a good job of preserving their own history and have published several useful books; see, for example, Rupert Fike, ed., Voices from the Farm (Summertown, Tenn.: Book Publishing Company, 1998). A brief article that combines insider and outsider perspectives is Albert Bates and Timothy Miller, "The Evolution of Hippie Communal Spirituality: The Farm and Other Hippies Who Didn't Give Up," America's Alternative Religions, ed. Timothy Miller (Albany: State University of New York Press, 1995), 371-77.

${ }^{13}$ A recent biography of Maharaj Ji/Maharaji/Prem Rawat is Andrea Cagan, Peace Is Possible: The Life and Message of Prem Rawat (Dresher, Penn.: Mighty River Press, 2007). For an examination of the Divine Light Mission in its communal years see James V. Downton Jr., Sacred Journeys: The Conversion of Young Americans to Divine Light Mission (New York: Columbia University Press, 1979).

${ }^{14}$ Walters provides his own extended account of his expulsion from the SRF in his book A Place Called Ananda, rev. ed. (Nevada City, Calif.: Crystal Clarity Publishers, 2001), 180-202.

15 Susan Love Brown, "Community as Cultural Critique," in Intentional Community: An Anthropological Perspective, ed. Susan Love Brown (Albany: State University of New York Press, 2002), chapter 8.

${ }^{16}$ John Ball, Ananda: Where Yoga Lives (Bowling Green, Ohio: Bowling Green University Popular Press, 1982), 89-96.

${ }^{17}$ Paramahansa Yogananda, Autobiography of a Yogi (Los Angeles: Self-Realization Fellowship, 1946).

${ }^{18}$ In addition to the works cited in the notes just above, see Susan Love Brown, "God and Self: The Shaping and Sharing of Experience in a Cooperative, Religious Community," in The Psychology of Cultural Experience, ed. Carmella C. Moore and Holly F. Mathews (Cambridge, U.K.: Cambridge University Press, 2001). An early useful monograph is Ted A. Nordquist, Ananda Cooperative Village: A Study in the Beliefs, Values, and Attitudes of a New Age Religious Community (Uppsala, Sweden: Borgströms Tryckeri AB, 1978).

${ }^{19}$ Although the larger Shambhala movement and its founder have been written about fairly extensively, the Shambhala Mountain Center has received limited attention. Two broader works that provide some basic information on the center are Rick Fields, "A High History of Buddhism," Tricycle 6, no. 1 (Fall, 1996): 54-55, and Charles S. Prebish, Luminous Passage: The Practice and Study of Buddhism in America (Berkeley: University of California Press, 1999), 165-66. 
${ }^{20}$ Robin Paris, "The Renaissance Community, Massachusetts," Mother Earth News, July-August, 1984, available online at <http://www.motherearthnews. com/Nature-Community/1984-07-01/The-Renaissance-CommunityMassachusetts.aspx>, accessed 27 March 2009.

${ }^{21}$ Directory of Intentional Communities: A Guide to Cooperative Living (Evansville, Ind., and Rutledge, Mo.: Fellowship for Intentional Community and Communities Publications Cooperative, 1991), 212.

22 Communities Directory: A Guide to Cooperative Living, 2d ed. (Rutledge, Mo.: Fellowship for Intentional Community, 1996), 292.

23 The most substantial scholarly monograph on the Brotherhood of the Spirit/Renaissance Community is Karol Borowski, Attempting an Alternative Society (Norwood, Penn.: Norwood Editions, 1984). More recently, a feature-length DVD that provided a retrospective look at the community was released: "Free Spirits: The Birth, Life, and Loss of a New-Age Dream," Acorn Productions, 2007; online at <http://www.acornproductions.net>, accessed 24 March 2009. ${ }^{24}$ James T. Richardson, Mary White Stewart, and Robert B. Simmonds, Organized Miracles: A Study of a Contemporary Youth, Communal, Fundamentalist Organization (New Brunswick, N.J.: Transaction, 1979). See also Joe V. Peterson, "The Rise and Fall of Shiloh," Communities no. 92 (Fall, 1996): 60-65.

25 A recent insider history of the Source Family is Isis Aquarian (Charlene Peters), The Source: The Untold Story of Father Yod, YaHoWa 13 and the Source Family (Los Angeles: Process, 2007).

${ }^{26}$ Max Weber, Economy and Society (New York: Bedminster Press, 1968), vol. 3, 1111-157. For a brief survey of post-Weberian scholarly thinking about charisma and charismatic leadership, see Thomas Robbins, "Charisma," in Encyclopedia of Religion and Society, ed. William H. Swatos Jr. (Walnut Creek, Calif.: AltaMira, 1998), 78-80. 
Reproduced with permission of the copyright owner. Further reproduction prohibited without permission. 